\title{
Competition and Cooperation in Japan's Industrial Districts
}

\author{
The Case of the Banshū Textile District \\ after World War II
}

\author{
Yasuhiro ŌTA \\ Tokuyama University
}

7 he COTTON INDUSTRY, which several decades earlier had led the field in the industrialization of Japan, revived rapidly after World War II through an expansion of exports to the United States. Once more it was the backbone of the country's economic growth until the beginning of the postwar high-growth period. Afterwards, heavy industries and the chemical industry took over as the country's leading industries. Still, despite the rise in wage levels and the fact that import barriers were kept low, contraction in the Japanese textile industry was mild compared to what happened in textile industries in the advanced nations of the West, at least up until the mid-1980s. The explanation for this can be found in the fact that, while the cotton industry contracted, the synthetic fiber industry grew, and small and medium-sized cloth manufacturers operating within vertical interfirm tie-ups used cooperative associations to their advantage and adapted to the shift toward small-lot production of many different types of fabric. ${ }^{1}$

${ }^{1}$ Michael L. Dertouzos, et al., Made in America (Cambridge: MIT Press, 1984); Douglas A. Farnie and Takeshi Abe, "Mengyō to Ajia shijō" [The cotton industry and the Asian market], in Chiiki shi no kanōsei [The possibility of regional histories], Kindai Nihon Kenkyū [Studies of modern Japan] No. 19 (1987). 
Cooperative relationships among enterprises are deemed to have been such an important factor in maintaining the competitiveness of Japan's textile districts that we might well wonder what sort of relationships they were, and how they came into being. We might also wonder what sorts of functions were fulfilled by cooperation among firms and by organizations like cooperative associations and public testing and research centers.

Before the onset of World War II, Japan's cotton industry had formed within itself an "elaborate industrial structure" made up of spinning companies, trading companies, and full-time weavers. In the principal cotton cloth industrial districts, the trend away from cottagebased work to factories and the use of power looms was proceeding at a fairly quick pace, and there were leading weavers who on their own could pursue product development, buying-in of cotton yarn, the production and sale of cotton cloth, and the procurement of funds.

They produced products that were different from what the weaving factories owned by spinning companies produced. Spinning companies, in turn, dyed and finished in their own shops the gray fabrics that had been woven by full-time weavers. The procuring of raw cotton for the spinning companies and the sale of their cotton yarn and cotton cloth was taken care of by trading companies, which had abundant access to information regarding the raw cotton, cotton yarn, and cotton cloth markets. And when it came to diffusion of market information and new technology, the industrial testing centers and industrial associations played an important role. ${ }^{2}$

With the introduction of a system linking exports and imports in the cotton industry in 1938, however, industrial district enterprises no longer were free to procure cotton yarn with the freedom they were accustomed to, for now they had to obtain their cotton yarn from a specific spinning company. ${ }^{3}$ After the war, when private-sector trade

2 Takeshi Abe, Nihon ni okeru sanchi men orimono gyö no tenkai [The evolution of the industrial district cotton textile industry in Japan] (Tokyo: University of Tokyo Press, 1989); T. Abe, "Mengyō" [The cotton industry], in Nihon sangyō hatten no dainamizumu [The dynamism of Japanese industrial development], ed. Haruhito Takeda (Tokyo: University of Tokyo Press, 1995), chap. 1.

${ }^{3}$ For more on the system linking exports and imports in the cotton industry, see Naosuke Takamura, "Mengyō yushutsunyū rinku-sei ka ni okeru bōsekigyō to sanchi kigyō" [The spinning industry and textile district under the export-import-linked system in the cotton industry], in Senji keizai [The wartime economy], Studies of Modern Japan No. 9 (1987). 
was allowed to resume, first spinning companies and then later chemical and synthetic fiber companies pushed ahead with the formation of keiretsu groups with industrial district companies and trading companies. ${ }^{4}$ At the same time they went on expanding exports, principally to the United States. Research on small and mediumsized textile companies after World War II has focused on the significance of this move to keiretsu grouping in competition among oligopolistic spinning companies and chemical and synthetic fiber companies, but there has been little interest in the relationship between keiretsu grouping and the changing fortunes of individual industrial districts. Furthermore, in their analyses of industrial districts producing spun fabrics, very few have taken notice of the huge variety in the way individual companies developed.

Of all Japan's principal spun-fabric-producing industrial districts, the one that maintained production the longest after World War I was the Banshū industrial district centered around Nishiwaki City in Hyōgo Prefecture. While most other such districts and the large spinning companies with weaving facilities were slowly cutting back their production in the 1970 s, the Banshū district kept up, or even increased, its high rate of exports as late as the mid-1980s (Table 1). This industrial district enjoys relatively convenient access to Osaka and Kobe, where many trading companies and port facilities are located (Figure 1). Its principal products are yarn-dyed fabrics for such things as shirts, blouses, tablecloths, and handkerchiefs. ${ }^{5}$ It specializes in product areas in which it does not face much competition from full-time weavers located in other textile districts or from spinning companies with weaving facilities.

${ }^{4}$ The present study pays special attention to the idea that the participation of the parent company in decisions on the content of operations and the conditions of major transactions of a company that has joined a keiretsu, as well as common use of information and cooperation in development, production, and sales among firms are all done on the assumption of long-term, stable dealings. In the case of the Banshū district, at least, the possession of capital was not a necessary condition when it came to building up such close relationships.

${ }^{5}$ In the production of yarn-dyed fabrics, finishing of the fabric is performed after colored yarns are woven into a colored pattern. This makes quality control and delivery control within the industrial district more complicated; also, because of the large number of labor-intensive operations, production costs are high and delivery periods are wider apart. Likewise, once a fabric is woven, no changes can be made to the color pattern, so reacting to changes in demand is seriously limited. 
TABLE 1. Changes in Production Quantities and Export Rates
among Cotton Staple Fiber Weavers

\begin{tabular}{|c|c|c|c|c|c|c|}
\hline \multirow{3}{*}{$\begin{array}{l}\text { Fiscal } \\
\text { Year }\end{array}$} & \multicolumn{4}{|c|}{ Production quantities } & \multicolumn{2}{|c|}{ Export rates } \\
\hline & \multirow[b]{2}{*}{ Nationwide } & \multicolumn{2}{|c|}{ Full-time weavers } & \multirow{2}{*}{$\begin{array}{l}\text { Spinning \& weaving } \\
\text { factories }\end{array}$} & \multirow[b]{2}{*}{ Nationwide } & \multirow[b]{2}{*}{ Banshū } \\
\hline & & Nationwide & Banshū & & & \\
\hline 1955 & $3,174,200$ & $2,289,351$ & 192,609 & 884,849 & 60.6 & 98.0 \\
\hline 1960 & $4,160,081$ & $3,591,295$ & 269,844 & 793,381 & 48.7 & 99.8 \\
\hline 1965 & $3,853,329$ & $3,617,114$ & 280,181 & 913,768 & 38.3 & 100.0 \\
\hline 1970 & $6,189,605$ & $3,882,605$ & 277,834 & 968,446 & 34.0 & 74.6 \\
\hline 1973 & $6,039,967$ & $3,562,638$ & 293,390 & 911,450 & 23.7 & 42.9 \\
\hline 1975 & $5,011,732$ & $3,030,122$ & 226,849 & 654,234 & 31.8 & 65.0 \\
\hline 1980 & $5,906,781$ & $3,324,466$ & 294,497 & 783,961 & 30.0 & 76.4 \\
\hline 1985 & $5,604,736$ & $3,072,210$ & 379,338 & 755,089 & 34.0 & 72.2 \\
\hline 1990 & $4,862,878$ & $2,477,873$ & 318,172 & 669,438 & 32.2 & 52.6 \\
\hline 1995 & $3,333,446$ & $1,477,799$ & 200,163 & 448,960 & 37.2 & 35.4 \\
\hline
\end{tabular}

Sources: The above figures have been compiled from Japan Cotton Staple Fiber Textile Industry Federation, Men sufu orimono tōkei nenpō [Annual report of cotton staple fiber textile statistics], editions for each fiscal year; Banshū Ori 21 Senryaku Iinkai [Committee on Banshū cloth strategies for the 21st century], Banshū ori 21 senryaku bijon [A vision for Banshū cloth strategies for the 21st century] (1994); and Hyōgo Prefecture Federation of Textile Cooperative Associations, Banshū ori no gaiyō [A summary of Banshū cloth], editions for each fiscal year.

Notes: The figures for production quantities for the years from 1966 on include synthetic spun fabrics. The figures for "Other types of trade" that are listed from the same year onwards are included with "full-time weavers."

The unit for production quantities is 1,000 square meters; the unit for export rates is $\%$. The export rate is equal to export volume divided by production quantity multiplied by 100 .

In earlier research on the Banshū industrial district, Hiroki Kakimoto did a comprehensive study that included the role of the "organizing agent" (see below) and producers other than weavers. ${ }^{6}$ But because his study contains little analysis of the business behavior of individual spinning companies and textile district companies, it suffers from the same problems that characterized other textile district research. Therefore in this paper I propose, while directing attention

${ }^{6}$ Hiroki Kakimoto, "Senzen no Banshū ori" [Banshū fabrics before the war], in Jiba sangyō no kenkyū [Studies of local industries], ed. Seiji Kaneko (Kyoto: Hōritsu Bunkasha, 1982), chap. 2; H. Kakimoto, "Sengo no Banshū ori" [Banshū fabrics after the war], ibid., chap. 3; and H. Kakimoto, "Banshū ori ryūtsū no mondaiten" [Problems in Banshū fabrics distribution], ibid., chap. 9. 


\section{Figure 1. The Principal Spun Fabric Industrial Districts}
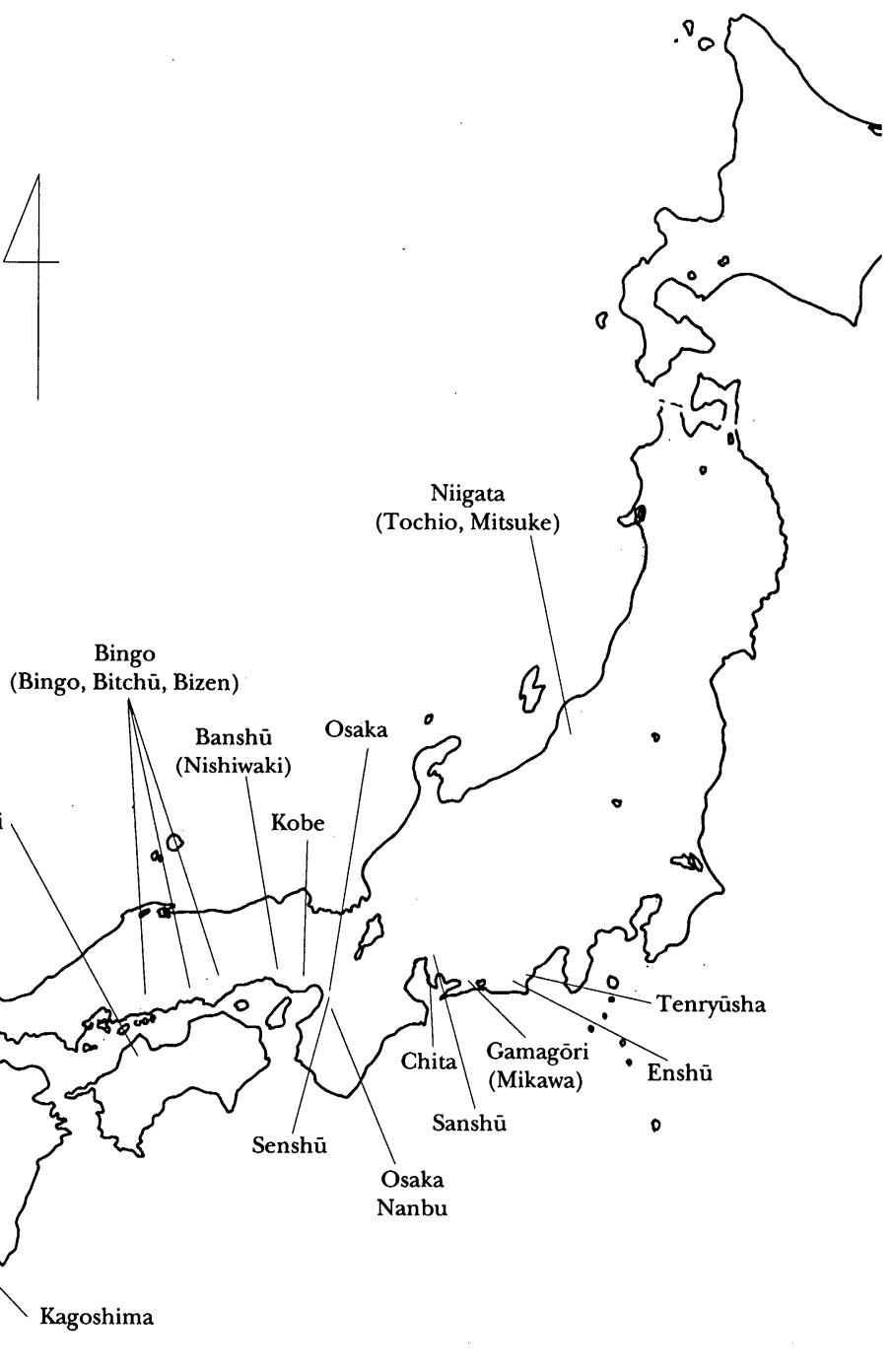

Source: Akira Kawai, Gurōbaru fasshon to shōhin kikaku [Global fashion and merchandise planning] (Tokyo: Bijinesu Sha, 1992), p. 188 (with slight additions by the author). 
to trends in individual businesses in the Banshū textile district from the time of wartime control right up to 1985, to investigate the changes that took place in the vertical and horizontal relationships of competition and cooperation that textile district companies were involved in, as well as the role played by cooperative associations and public testing and research centers. I also propose to consider how these factors might have affected the changing fortunes of Banshū textile district.

\section{SPINNING COMPANY KEIRETSU GROUPINGS AND THEIR DEVELOPMENT}

\section{The Influence of Wartime Control}

Between the two world wars, the Banshū district made rapid growth as a producer of yarn-dyed fabrics for export. Leading weavers in the district, receiving support from public testing and research bodies and from cooperative associations, were developing a variety of products. After purchasing cotton yarn from cotton yarn traders, they had these processed by dyers, by their own weaving factories and/or by a host of small and extremely small weavers, and by finishing shops. The finished cloth was then sold by them to cotton cloth brokers and textile trading companies. ${ }^{7}$

When the war between Japan and China began in 1937, the government restricted imports of raw cotton because of the need to import munitions, with the result that the domestic market price of cotton goods soared and cotton cloth exports fell. In 1938 the Ministry of Commerce and Industry put a curb on consumption of domestic-oriented raw cotton and, to stabilize cotton cloth exports, banned any domestic-oriented production of cotton or cotton-rayon cloth except what was for military use. At the same time it set up a system linking exports and imports in the cotton industry. Under this system spinning companies were given permission to import raw cotton in proportion to the amount of cloth they exported. The cotton yarn they produced they either had to weave into cloth in their own factories or had to hire out to be woven by full-time weavers. As a rule, each full-time weaver was allowed to receive yarn for weaving from

${ }^{7} \mathrm{~T}$. Abe, The Evolution of the Industrial District Cotton Textile Industry in Japan (see note 2 above). 
only a single spinning company. ${ }^{8}$ The result was that the leading weavers in Banshū were no longer capable of independent development, production, or sales activities. At the same time, the spinning companies were forced to compete with one another for the services of weavers if they wanted to raise their export figures. Even spinning companies that previously had very little to do with Banshū businesses now started dealing with leading weavers and cotton yarn/cotton cloth dealers who would take on the burden of advancing the spinning companies' yarn for weaving and of overseeing contracting out. In 1940 the Ministry of Commerce and Industry announced a "General Plan Regarding Integration of Cloth Manufacturers" and pushed for industry-wide unification by making a minimum of 300 looms the standard for any individual weaving business. Cotton yarn and cloth traders in Banshū handled weaving yarn procurement and production management within the integrated system.

As the war dragged on, it became difficult for the woven cloth industry even to survive. From 1943 on, the government demanded that plant and equipment be handed over to it, and in Banshū 252 out of 442 factories were closed or turned into military factories. At this time one leading weaver, Man'emon Maruyama, offered all of his looms to the government. ${ }^{9}$

\section{DEVELOPMENT OF THE AMERICAN MARKET AND VERTICAL/HORIZONTAL ORGANIZATION}

After the war the Japanese government in 1948 permitted the production of spinning company brand goods and allowed contracts between overseas buyers and private sector companies to be entered into freely. In 1949 the government sold its stock of weaving yarn to the private sector. ${ }^{10}$ These measures made it possible for spinning companies and textile trading companies to carry on business activities

${ }^{8}$ N. Takamura, "The Spinning Industry and Textile District" (see note 3 above).

${ }^{9} \mathrm{H}$. Kakimoto, "Banshū Fabrics before the War"; Yasuhiro Ôta, Dainiji taisen-go ni okeru Banshū sakizome-orimono-gyō no tenkai to kōzō [The evolution and structure of the Banshū yarn-dyed fabric industry after World War II]. Ph.D. dissertation, Osaka City University, 2000.

${ }^{10}$ Ministry of International Trade and Industry (MITI), Shökō seisaku shi [A history of commercial and industrial policies], vol. 16, The Textile Industry, Part 2 (1972). 
free of government control, while in the weaving districts extremely small weavers proliferated when prices soared as a result of materials being in short supply.

Because of the loss of colonial markets, an increase in exports of cotton cloth from India, and self-sufficiency in cotton products in the countries of South America after the war, the spinning industry experienced difficulty in exporting the gray fabric that had been its principal commodity before the war. For this reason spinning companies moved into dyed and finished fabrics and into augmenting dyeing and finishing facilities in their own factories. At the same time they farmed out their own brand cloth to be finished by textile district companies that were a part of their own keiretsu groups. The fact that another system linking exports and imports was put into effect beginning in October 1952, a system in which there was a higher rate of linkage for finished fabrics than for gray fabrics, was a major factor in the surge toward dyed and finished fabrics.

The yarn-dyed fabrics that were the principal commodity of the Banshū district came in many varieties, their production processes were complicated, and they required special equipment. Now, the spinning companies had little of the knowledge needed to produce and to sell such items, but, rather than setting up a vertical integration of the dyeing, weaving, and finishing processes, they built up cooperative relationships (based on the assumption of a stable, long-term business relationship) between themselves and merchants or leading woven cloth businessmen who prior to the war had been cotton cloth traders or leading weavers. These merchants/woven cloth businessmen were known as "organizing agents," and they had offices set up in Osaka and Kobe, where they negotiated with trading companies over such things as the brand products of the spinning companies or products that overseas buyers wanted to be made according to their specifications. ${ }^{11}$

The organizing agents would conclude provisional contracts with trading companies, then have talks with the spinning companies. Where the spinning companies could accept the conditions for the sale of their yarn for weaving, they would enter into contracts with the trading companies, advance the weaving yarn to the organizing

11 The word for "organizing agent," sanmoto, had existed from before World War II, but it was not in use in Banshū immediately after the end of the war. 
agent, and consign production to him. While on the one hand an organizing agent who was part of a keiretsu group functioned as a sort of business organization of the spinning company, he also gave instructions to producers in the industrial district, paid processing fees, and conducted delivery control (from negotiations with the trading company right up to the loading of the cargo on a ship). If there were any transactions that would seem unlikely to be profitable for the spinning company, or transactions mediated by an organizing agent who did not have a close relationship with the spinning company because his reliability was still an unknown factor, no contract would be made regarding consignment of processing, and the organizing agent would have to purchase the weaving yarn himself.

In the Banshū district, fabrics were produced in which cotton yarn of No. 20 count was employed, but Toyōbō developed a gingham that employed No. 40 count cotton yarn in an effort to upgrade to a higher standard of cloth. Because it was necessary to meet stringent quality criteria regarding dyeing for exports of fabrics to the United States, spinning companies sent their own technicians to Banshū to conduct technical guidance, or they set up merged companies, or took other measures, all with the aim of supporting the modernization of dyeing factories and shops. Thus, for example, Tōyōbō lent money for the establishment of new factories, and in 1954 Kurehabō established a dyeing and finishing business through a merger with an organizing agent. Other ways in which the technical levels of the weaving industry were raised included the development of looms that could weave broader cloth, and the addition of droppers and highperformance dobbies.

The Textile Laboratory in the Hyōgo Prefecture Central Industrial Testing Institute, which was a public testing and research body, also supported the improvement of dyeing and cloth weaving technology. On the basis of a program of guidance sponsored by a Committee to Stimulate Weaving in Banshū from December 1949 to July 1951, the Textile Laboratory conducted experimental weaving of cotton goods using fine-count yarn and worked for the improvement of dyeing and starching techniques. It also provided technical guidance in regard to poplin broadcloth, figured broadcloth for which dobbies were employed, check-striped fancy-weave gingham, and check-striped handkerchiefs. From April 1949 it instituted a "dyeing and weaving 
training system" (for 20 trainees at a time over a period of one year), and to provide guidance in methods of starching yarn of fine count it invited starching technicians from Enshū. ${ }^{12}$

Because of the success met by expanded exports of 40-count gingham and some other products to the United States, the volume of woven goods produced in the Banshū district jumped quickly from 69 million square meters in fiscal 1952 to 193 million square meters in fiscal 1955. During this interval the volume-base export percentage fluctuated in the $98 \%$ range, while the percentage of the production volume held by exports of gingham to the United States rose from $16.6 \%$ to $43.9 \%$. But in 1956 a system of self-imposed control on exports of cotton goods to the U.S. came into place, and the component of U.S.-oriented fabric exports fell to $26.3 \%$ of the production volume for fiscal 1959. Furthermore, since the export quota was allotted to trading companies on the basis of their export performances in the preceding fiscal year, the initiative in business negotiations shifted from the spinning companies to the trading companies.

In reply to this kind of situation, Tōyōbō used stronger tie-ups with Banshū companies and stringent inspections to carry out a thorough control of quality and delivery in an effort to raise the level of consumer trust in Tōyōbō brand products. At the same time it gathered information from its overseas branch offices in order to develop woven goods with higher added values. It transferred patents, production skills, and even equipment from its own factories when small and medium-sized companies could not afford to buy such equipment. And it encouraged the introduction of dobbies, which made it possible for complex fabric constructions to be woven. In 1957 Tōyōbō moved its Sanforize finish machines to Tōyō Senshoku Kōgyō's Nishiwaki Plant, thus creating the first instance of a unified production process within a keiretsu group in the Banshū district. When it made a decision on the conditions for Tōyō Senshoku Kōgyō business transactions, Tōyōbō gave priority to maintaining the working rates of the equipment, and to this end it secured orders by keeping processing fees low. This was based on the idea that orders for mass production items would keep equipment operating steadily and would enable the company to put more energy into planning and development of new fabrics. Tōyō Senshoku Kōgyō also received process-

${ }^{12}$ H. Kakimoto, "Banshū Fabrics after the War." 
ing orders from companies outside the keiretsu; this contributed to giving higher added value to Banshū products. There were only a few spinning companies that, like Tōyōbō, built exclusive, stable relationships. Banshū district companies' dealings had to a certain extent been wide open, ${ }^{13}$ but as a result of competition, improvement of product development and stricter control of quality and delivery periods had come to be demanded by other companies from within the Banshū district as well.

As a result of keiretsu grouping, organizing agents were able to secure advances of weaving yarn from spinning companies and the handling of spinning companies' brand goods, but they faced fierce competition when it came to the sale of fabrics. It is believed that restrictions on the volume of exports to the United States and the superior position of trading companies in business negotiations led to fiercer competition among organizing agents. And the fierce competition among companies in the same trade strengthened the inclination of organizing agents to seek cooperation. In 1955 a Banshū Textile Traders Cooperative Association made up of sixteen organizing agents was organized, thus establishing a forum in which organizing agents could exchange information. From the following year meetings were held of those in charge of business. At these meetings they exchanged information on textile market conditions, made a survey of the fees all the organizing agents were paying to dyers in order to consider a suitable level of dyers' fees, ${ }^{14}$ and compiled a blacklist of unscrupulous cloth weavers. Cooperation in regard to textile unit prices was difficult to achieve, but the exchanges of information made it easier for organizing agents to decide on appropriate transaction conditions and to find businesses to whom work could be contracted out,

${ }^{13}$ According to a 1964 survey, there were few organizing agents who relied for all of their sales on a single spinning company. Also, while most of the spinning companies that formed keiretsu in Banshū district increased the number of organizing agents and cloth weavers that they dealt with, in all except the Töyōbo keiretsu the degree of cloth weaver dependence on specific spinning companies fell. In the Kanebö keiretsu, competitive relationships within the keiretsu group were maintained, and the spinning company was in charge of sales activities. See the Ph.D. dissertation cited in note 9.

${ }^{14}$ The worst problem from the point of view of quality control in dyeing was the use of low-cost sulfide dyes, which made woven fabrics disintegrate. Consequently organizing agents found it necessary to prevent the use of such sulfide dyes by paying a level of fee that would enable dyers to make a profit even if they used proper dyes. 
and in this way it was effective in preventing ruinous price wars or loss of Banshū's good reputation through slipshod manufacturing.

The organizing agent business was composed of several different layers. Besides the organizing agents who were part of the keiretsu groups of the large spinning companies, there also were organizing agents who dealt with the comparatively small spinning companies that sprang up after World War II as well as with small and mediumsized commercial trading companies and brokers who disposed of a portion of the products that organizing agents had taken orders for. Another thing to note is the fact that the development of the Banshu district was accompanied by the emergence of some extremely small new organizing agent companies.

In yarn-dyed fabric transactions some mechanism needed to be in place in order that all the things that were involved in a business negotiation-the color, the construction, the quantity, and so on of each of the many different fabrics-could be supplied together. When limitations on production techniques and skills and on production capacity made it impossible for certain products to be taken care of by existing subcontractors, the various individual organizing agents were able to contract out and sell a large variety and large quantities of fabrics by entrusting handling of them to smaller agents or brokers, or by receiving information from those same agents or brokers in regard to producers who were able to become subcontractors. The brokers operating freely within Banshū also took on the function of presenting to the bigger organizing agents information on such things as the designs and kinds of fabrics being woven in the weaving factories. In this way they helped spread information on new products very quickly among Banshū district companies. ${ }^{15}$

\section{RESPONSES TO SYNTHETIC FIBER AND RISING WAGES}

As synthetic fiber production technology developed, spinning companies began producing synthetic fiber products (these were not included in the self-imposed control agreement on exports to the United States). But the tight monetary policies of 1964 and the enforcement

${ }^{15}$ For more detailed information, see the Ph.D. dissertation of Y. Ōta (cited in note 9 above). 
of the Law on Special Measures for Equipment Etc. in the Textile Industry made frequent cutting back of operations difficult, and the cotton yarn market price took an abrupt dive. Even in the synthetic fiber industry, as lively as it was with all its newcomers and its growth in production capacity, the unit prices of its products (which were mainly nylon) plummeted in 1964-65. Kurehabō's situation deteriorated so much that it was merged into Tōyōbō in 1966; in 1969 Nichibō merged with Nippon Rayon to form Unitika. ${ }^{16}$ Such company reorganizations had an effect on competition and product specialization within enterprise keiretsu groups in the Banshū district. Tōyōbō, which had in its group Naigai Orimono and Ozawa Sen'i, added to the list of its subcontractors the organizing agents of the old Kurehabō keiretsu, Kuwamura Sen'i and Daiichi Mengyō. Unitika, which was dealing mainly with two Banshū organizing agents, in 1970 began producing striped fabrics and chambray in a Sekigahara factory, in order to offset its losses in its own polyester cut staple operations; then in 1974 it installed equipment in the same factory to produce multicolored yarn-dyed fabrics.

The production of cotton yarn in postwar Japan reached its peak in 1961, but just when overproduction was overcome in the mid1960s the demand for synthetic fiber products steadily increased. The production of cotton, staple fiber, and synthetic fiber spinning yarns went from 759,742 tons in 1965 to 875,059 tons in $1973 .{ }^{17}$ When demand for cotton-polyester fabrics for shirts expanded after the development of the permanent press finish, the Banshū district enjoyed a boom, since cloth for shirts and blouses was its principal product. Thus, production of cotton-polyester fabrics rose by $640 \%$ between 1965 and 1970 , and from being only $8.1 \%$ of the total production in 1965, to $51.7 \%$ in 1970 . Having started out as a cotton cloth producing district, Banshū began by exporting its cotton-polyester fabrics as gray fabrics, but because all the finishing companies rushed to get in permanent press finishing equipment as demand increased,

${ }^{16}$ Japan Chemical Fibers Association, Nihon kagaku sen'i sangyō shi [The history of Japan's chemical fiber industry], 1974; Japan Spinners' Association, Zoku sengo böseki shi [A history of postwar spinning, continued], 1979.

${ }^{17}$ See the second half of 1966 and 1974 editions of Bōseki jijō sankōsho [A reference work on spinning conditions], a semi-annual publication of the Japan Spinners' Association. 
the district carried out a switch from gray fabric exports to finished fabric exports. At the same time, the Banshū Weaving Industry Cooperative Association took advantage of the structural improvement projects that were based on the Law on Special Measures for Specially Designated Textile Industries' Structural Improvement to move and rebuild its finishing plant in 1969 . In the period 1968-70, production of permanent press finished fabrics in Banshū soared from 86 million yards to 138 million yards, while gray fabric production fell from 57 million yards to 44 million yards.

In 1971, however, conditions for exports to the United States turned for the worse because of a bilateral agreement concluded between Japan and the United States in regard to cotton, wool, chemical, and synthetic fibers and because of a revaluation of the yen. On the other hand, American companies that sewed cloth into shirts and so on or retailed the finished goods were faced with rising costs for sewing labor; also, their access to direct imports from Japan was being restricted. They increasingly entrusted production to companies in Hong Kong or else made direct investment in such companies. Banshū reacted by expanding exports of cotton-polyester cloth to sewing factories in Hong Kong. In 1972, $27.0 \%$ of its export-oriented fabric production was directed to Hong Kong. The sewn products were then exported to the United States. Banshū's rate of exports, which had been close to $100 \%$ of all it produced in all the years from 1952 on, dropped to the $70 \%$ percent range from 1970 on, but its export-focused market makeup remained unchanged. ${ }^{18}$

In order for the Banshū district to maintain its international competitiveness, it had to neutralize the effects of rising wages and the shortage of labor that became very serious in the second half of the 1960s. The cloth weaving industry had been heavily dependent upon

${ }^{18}$ For more on textile industry policies, see Ippei Yamazawa, "Sen'i sangyō" [The textile industry], in Nihon no sangyō seisaku [Japan's industrial policies], ed. Ryūtarō Komiya, Masahiro Okuno, and Kōtarō Suzumura (Tokyo: University of Tokyo Press, 1984), chap. 14. For the development of Hong Kong's textile industry and exports to Hong Kong of Banshū's products, see H. Kakimoto, "Banshū Fabrics before the War"; Tōyō Senshoku Kōgyō, Tōyō Senshoku Kōgyō sanjūnen shi [A thirty-year history of Tōyō Senshoku Kōgyō] (1982); Eisuke Daitō, "Honkon ni okeru bōsekigyō no hatten" [The development of the spinning industry in Hong Kong], in Kokusai hikaku, kokusai kankei no keiei shi [A business history of international comparisons and international relations], ed. Hidemasa Morikawa and Tsunehiko Yui (Nagoya: Nagoya University Press, 1997), chap. 11; and Y. Ōta, Ph.D. dissertation cited in note 9 above. 
a labor force of young women from the countryside, and producers tried to avoid the rising and freezing of wage costs by contracting out the labor-intensive and operationally simple preparatory processes to farming families and elderly people-in other words, by turning it into a domestic or cottage industry. Between 1964 and 1972, in the cooperative associations that belonged to the Hyōgo Prefecture Textile Cooperative Association Federation, ${ }^{19}$ the number of looms per Association member fell from 23 looms to 15, and the number of employees in each Association member fell from 17 people to 6 . On the other hand, the restrictions on equipment that took effect in 1964 had taken hold and government buying up of equipment in times of recession had become standard practice. These combined to put a premium on the ownership of looms and limited the opportunities for cost reduction through expanding the scale of cloth weaving factories. This was because any company that wanted to expand its production capacity by replacing looms or adding more looms was forced to purchase loom ownership rights. Even though the replacement of looms was stimulated by structural improvement projects based on the Law on Special Measures for Specially Designated Textile Industries' Structural Improvement, the development of shuttleless looms for yarn-dyed fabrics that could raise production efficiency substantially was lagging behind. Because of this, companies outfitted with old looms and struggling with mediocre business performance, were still able to continue operating, and they were not readily inclined to let go of their right of ownership. ${ }^{20}$

The increase in extremely small companies in the cloth weaving industry was not due only to the scaling down of already existing companies; some of it was due to the creation of new companies. Demand for yarn-dyed fabrics in the 1960s was stable, but the general trend

19 The Hyōgo Prefecture Textile Cooperative Association Federation is an alliance of Banshū district associations.

${ }^{20}$ For more on cooperative association operations in Banshū, see Shōji Minami, "Banshū ori no soshikika, kumiai katsudō" [Systemization and association activities in Banshū weaving], in Studies of local industries, chap. 10 (see note 6 above). For more on the problems with the equipment registry system, see Kikutarō Takizawa, "Kōzō fukyō sangyō to chūshō kigyō no sonritsu jōken" [Structurally depressed industries and the conditions for subsistence of small and medium-sized businesses], in Keizai kōzō hendō to chūshō kigyō [Changes in economic structure and small and medium-sized businesses], ed. Taikichi Itō (Tokyo: Chūō Keizaisha, 1987), part 1, 2. 
for weaving fees was to rise. As a result, maintenance workers whose wages reached their upper limits once they turned thirty, and farmers who were doing weaving on the side, were attracted into the cloth weaving industry. Membership in the Hyōgo Prefecture Textile Cooperative Association Federation grew from 1,055 in fiscal 1964 to 1,483 in fiscal 1970. According to a survey of fifty-two companies that had received loans from the Akashi branch of The People's Finance Corporation between July 1967 and February 1970, 47 of the company owners (or $90.4 \%$ ) were former maintenance workers. More than half of the 52 companies owned from 4 to 8 looms. Approximately $20 \%$ of those surveyed were leasing out looms that they could not put to use in their shops because of the labor force shortage; they were leasing them out through shops that sold machine parts and tools needed for producing cloth. Because of the entry of farming families into the business, cloth weaving factories and shops spread out into farming regions as well. ${ }^{21}$

The dyeing industry was carrying out hank dyeing; this is a laborintensive process that easily results in patchy or uneven dyeing. Public testing and research bodies and cooperative associations began doing research on, and began introducing, new dyeing techniques, thus making a large contribution to improving labor productivity and quality. The Hyōgo Prefecture Textile Industry Technical Center (Hyōgo-ken Sen'i Kōgyō Shidōsho) began experimenting on cheese dyeing in 1962, and the Hyōgo Prefecture Textile Dyeing Industry Cooperative Association set up a special committee in 1964 to do research on cheese dyeing. In fiscal 1967 cheese dyeing machines were introduced into seven companies, and beam dyeing was introduced for the first time throughout the country. By means of the introduction of such dyeing techniques it became possible to effect mechanization and a large reduction in time-consuming operations preparatory to dyeing; it also became possible to prevent inequality in texture

${ }^{21}$ Business Affairs Department, Akashi Branch, "Banshū orimonogyō ni okeru shōreisai kigyō no shinki kaigyō" [New business starts by small and extremely small businesses in the Banshū textile industry], in Chōsa geppō [Survey monthly], comp. Survey Division, The People's Finance Corporation, No. 111 (1970); Yũichi Takeuchi, "Banshū men orimonogyō chiiki ni okeru shakaiteki bungyō no shinten to nōgyōteki kiban" [The development of social division of labor and agricultural foundations in the Banshu cotton textile industrial district], Keizai chirigaku nempō [Annals of the Japan Association of Economic Geographers], vol. 29, no. 1 (1983). 
caused by broken yarn or uneven yarn. When the government bought up surplus equipment in the wake of self-imposed control on exports to the United States, seven extremely small dyeing businesses either went out of business altogether or switched to another business, so that in fiscal 1972 the number of dyeing companies stood at nineteen. ${ }^{22}$

INDEPENDENCE AND RATIONALIZATION UNDER CONDITIONS OF INCREASED DEMAND

First there was appreciation of the yen in the wake of the switch from a fixed exchange rate to a floating exchange rate. This was followed by the first "oil shock" in October 1973. In Banshū the volume of fabric production fell from 293 million square meters in fiscal 1973 to 227 million square meters in fiscal $1975 .{ }^{23}$ Spinning companies began to have restricted access to funds, and organizing agents were advanced weaving yarn more infrequently and had to purchase the weaving yarn themselves. No longer able to expect growth through increased demand for spinning companies' brand products, organizing agents strengthened their tie-ups in sales activities with trading companies (which had abundant access to information about the weaving yarn and textile markets). They also promoted higher-quality goods (such as gingham of a finer count of yarn). Organizing agents now had to procure from various kinds of spinning companies the weaving yarn needed to develop new products. In doing business with a number of spinning companies, the agents were able to compare such transaction conditions as the prices of weaving yarn. ${ }^{24}$

Despite all these changes, Banshū production volumes steadily increased from the end of the 1970s through to 1987, thanks to the worldwide spread of the fashion of wearing a combination of colored shirts and jeans. From 1976 to 1986 Banshü's exports maintained a level over $70 \%$. In the case of export-oriented sales, organizing

${ }^{22}$ H. Kakimoto, "Banshū Fabrics before the War."

${ }^{23}$ Banshū. firms reduced operations and carried out joint acceptance of orders.

${ }^{24}$ The former organizing agent for the Kurehabō keiretsu, Daiichi Mengyō, began dealing with Nittōbō, which had lost its consigner in the Banshū district because its organizing agent went bankrupt in 1977, and provided Nittōbō with several businesses to which it could consign paid processing work. 
agents received offers from buyers and received payment for the fabrics either in cash or in short-term bills (notes); as a result, planned selling remained possible and there was no notable worsening of money supply. The prices of textiles also improved from 1975 on, to a level that exceeded the rising costs of cotton yarn and weaving fees, and they remained stable until the mid-1980s. ${ }^{25}$

During the growth in demand for colored shirts and jeans, some of the spinning companies pushed ahead with new arrangements with Banshū businesses. Thus, for instance, Tōyōbō, anticipating that there would be a rise in demand for colored shirts, in 1973 established a cloth weaving company in a joint venture with its organizing agent, thus expanding production capacity within its keiretsu. Similarly, Kurabō, aiming at increasing sales of weaving yarn through aggressive use of consigned production, organized a jeans production team, at which time it chose Banshū dyeing and finishing businesses to be the ones to which it would consign finishing. One reason for this was that the Banshü district had some organizing agents who maintained a high rate of paid processing. Another reason is that many of the organizing agents who had become members of spinning company keiretsu in the postwar revival period had either maintained stable sales or increased them in all the subsequent years.

While existing cooperative relations between spinning companies and the district's businesses were to a certain extent being maintained in this way, some organizing agents in the district became independent of the spinning companies and grew by evolving a variety of market and production strategies. Of the leading organizing agents that integrated and/or expanded their dyeing, weaving, and finishing processes, for example, the largest organizing agent in Banshū, Ozawa Sen'i, developed its sales activities around the domestic market, closing down its own cloth weaving factory. Kuwamura Sen'i, which had been incorporated into the Toyōbo keiretsu when the spinning company Kurehabō was merged, downsized its own cloth weaving factory, yet it still managed to increase sales a great deal because

${ }^{25}$ The fact that yarn-dyed fabrics could not be produced in countries where dyeing technology was undeveloped was an important factor behind Banshū's ability to maintain production. In fabric dyeing, it is possible to have the cloth produced overseas and then do the dyeing in Japan, but when it comes to yarn-dyed fabrics, which are produced in the order of dyeing, weaving, and finishing, having an intermediate process done overseas presented too many difficulties. 
it adopted a flexible response to changes in export and domestic demand and expanded its product lines into men's and women's clothing fabrics. Tokuoka Shōten, which owned its own finishing factory, adopted the opposite course: it pushed ahead with expansion of its own cloth weaving factory and succeeded in drastically reducing its costs through mass production. In addition, a certain cloth weaver who was doing consigned weaving of tablecloth noticed that existing organizing agents were not putting much effort into tablecloths for business use, so from 1977 he energetically developed the market. Later he went into development of cotton yarn jointly with a spinning company. He is only one example of the small-scale organizing agents who started up businesses independently of existing organizing agents and grew by developing their own fabrics. Producers and new small businessmen like these were able to bring about the development and production of new fabrics by organizing producers in their vicinity. As we see in Table 2, the number of new organizing agents exceeded the number of those who abandoned the business or went bankrupt, and almost all of the agents whose sales figures were high either increased those figures or to a certain extent maintained them.

In the midst of stability in demand for plain fabrics (whose production efficiency was high) and stability in weaving fees, from the end of the 1970s spinning companies were eager to introduce the shuttleless looms. These produced fabrics of more uniform quality and greatly increased labor productivity. ${ }^{26}$ In Banshū $17.3 \%$ of all the looms being used were the shuttleless looms, and the production volume per loom rose from 11,839 square meters in 1978 to 17,079 square meters in 1985. Development of shuttleless looms for yarn-dyed fabrics lagged behind that for gray fabrics; they made up $13.3 \%$ of the shuttleless looms (not including narrow-width looms) being used in Banshū at the end of March 1985. This meant that Banshū ranked second out of the eight industrial districts involved on a relatively large scale in the production mainly of spun fabrics. ${ }^{27}$ Because labor pro-

${ }^{26}$ According to a survey of the Banshū Organizing Agents Cooperative Association, workers' wages accounted for $22.0 \%$ of the unit cost of cotton-polyester gingham in the first quarter of 1978. It was the second highest cost factor, following the cost of the weaving yarn, which accounted for $36.4 \%$ of the unit cost.

${ }^{27}$ The top-ranking industrial district was Mikawa (18.4\%). Sanshū (see Fig. 1 for all these names) ranked about the same as Sanshū, at $13.2 \%$. Figures for Osaka Nanbu, Enshū, and Chita were $8.4 \%, 4.2 \%$, and $3.2 \%$, respectively. Production figures for the 
TABLE 2. Fluctuations in Sales Results among Organizing Agents

\begin{tabular}{lccccc}
\hline Sales & 1970 & 1975 & 1980 & 1985 \\
Totals & 26 & 27 & 36 \\
8-10 billion yen & - & - & - & \\
6-8 billion yen & - & &
\end{tabular}

Sources: The above figures were compiled from Shin'yō Kōkansho Sōgō Jigyōbu, ed., Zenkoku sen 'i kigyō yöran [A catalogue of textile businesses nationwide], annual editions; Nihon Ginkō Chōsa Tōkeikyoku [Japanese Banks Survey and Statistics Bureau], Meiji ikö oroshiuri bukka shisū tōkei [Statistics on wholesale price indexes since the Meiji period] (1987).

Notes: The materials that were used for 1970,1975 , and 1980 include legal bodies capitalized at 2 million yen and above and wholesalers with an annual trade of 50 million yen and above, while the materials for 1985 included wholesalers with an annual trade of 50 million yen and above. Almost all organizing agents who were members of the organizing agents' cooperative association and some of those who were not members are included.

For the sales figures I chose the settlement period closest to the end of each year, but for several of the businesses the month in which their settlement period ends is not clear. The figures were deflated by the cotton textile wholesale price index $(1970=100)$.

The figures within the arrows indicate the number of businesses that moved. Among the new businesses are included a very few that were already doing business but had not been included in earlier lists.

ductivity improved as a result of increased demand and mechanization and because processing fees were stable, hardly any dyeing or finishing businesses went bankrupt or closed down. Some of the dyeing businesses secured orders by taking on more orders from outside

years from the mid-1980s on show that the introduction of the shuttleless looms was an important factor determining whether production increased or fell, since changes were more moderate in Banshū and Sanshū than in Osaka Nanbu, Enshū, and Chita. 
the district, such as the dyeing of yarn for knit fabrics. Some of the finishing businesses purchased a variety of finishing machines and aimed at differentiation and high value-added products. Banshū producers were capable of small-lot production as well, but because they were able to secure orders for big lots thanks to the stability of exports, they did not suffer any major deterioration in the operating capacity of their equipment. Also, higher fees were paid for small-lot orders than for big-lot orders. ${ }^{28}$

\section{CONCLUSION}

In the case of the Banshū industrial district, the important factors that made it possible for businesses in the district to develop the American market in the period from the resumption of private sector trade after the war up the high economic growth period and to respond to technological changes in products and production were: 1) the strengthening of vertical tie-ups in the form of enterprise keiretsu; 2) cooperation among people in the same trade; 3) the support given to businesses in the district through such organizations as cooperative associations and public testing and research centers. These three elements were mutually complementary.

The export-import link system in the cotton industry, whose connection with keiretsu groups is often commented on, fostered closer relations between the district's businesses and specially designated spinning companies, prohibited independent business activities by the leading weavers, and helped spread the form of transaction known as contracted production by means of paid processing. Later, leading weavers lost some of their looms as a result of governmental regulation, and after the war extremely small weavers proliferated. After private sector trading resumed, spinning companies brought many of the district's businesses into their own keiretsu groups, but three postwar conditions were important at that stage: 1) the loss of prewar colonial markets and the importance given to the United States market; 2) the orientation of the spinning companies towards

\footnotetext{
${ }^{28}$ See Y. Ōta, The Evolution and Structure of the Banshū Yarn-Dyed Fabric Industry after World War II (Ph.D. dissertation).
} 
processed fabrics; 3 ) the existence of large numbers of extremely small weavers.

Within the keiretsu groupings of the spinning companies there was a division of labor between the spinning companies, which took care of quality control and the introduction of new technology, and organizing agents, who took care of sales activities and the organizing of producers. The products were the brand goods of each spinning company and goods specified by overseas buyers; almost all of the products were thus export-oriented. In transactions involving merchandise for export overseas, orders were secured early, large quantities were involved, and the organizing agents did not need to bear the burden of storage. Banshü businesses had some connection with the development of the spinning companies' brand goods, but their costs were comparatively small, and they were able to retrieve costs in the context of long-term, large-volume transactions. Furthermore, because organizing agents were advanced the yarn for weaving by the spinning companies, they could get by with fewer funds, and conditions for receiving payment for the fabrics were good. Producers were able to plan their production, and their equipment was kept running at a steady rate. When new technology requiring large outlays of money had to be introduced or quality control had to be tightened, the spinning companies responded by sending their own technicians or setting up joint companies. In those keiretsu groupings that were especially closely bound together, the whole group worked as if it were a single factory.

Some problems could not be solved by keiretsu groupings, such as dealing with many different orders, enhancing the district's reputation as a district, and production adjustment. These problems were responded to by cooperation among people in the same trade and by production policies. For example, by exchanging information among themselves, the organizing agents were able to avoid dealing with disreputable weavers, were able to locate suitable subcontractors, and were able to discover appropriate transaction conditions to prevent producer quality control from degenerating. To fill orders for many different items and in large quantities, organizing agents farmed out orders to other organizing agents or obtained information from them regarding places to which work could be contracted out. When overproduction of fabrics became a problem, cutting back 
on operation in the various trades, government restrictions on production capacity, and government purchasing of surplus equipment were some of the measures adopted. But such measures only served to reduce the number of existing weaving factories and invite the entry into the trade of numerous extremely small weavers. The result was increased competition in the Banshū weaving industry.

It is believed that competition between enterprise keiretsu groups had repercussions on Banshū businesses that did not have close relationships with the specially designated spinning companies, forcing the latter to improve their quality control capacity and to introduce new production technology. Cooperative associations and public testing and research organizations went beyond keiretsu frameworks and assisted district businesses to adapt to changes in products and production technology. The cooperative associations of people in the textile industry kept their members informed of the various types of government support (such as structural improvement projects) and urged them introduce new weaving machinery. It also established a finishing factory with a view to achieving higher added value benefits. The public testing and research bodies educated people in regard to dyeing and weaving technology and, in cooperation with the cooperative association of people in the dyeing industry, contributed to the development and introduction of new dyeing techniques.

But the voluntary restraints on exports to the U.S. as a result of trade friction, the shortage of labor and rising costs, the development of textile industries in other countries in Asia, and other factors gradually led to a worsening of the export environment. Then there was the recession in the mid-1960s, followed by the first "oil shock." Spinning company keiretsu were reorganized and reduced in numbers. For Banshū to maintain its competitiveness in these conditions, it would have to develop markets through planning and developing fabrics, go in for small-lot production of a large variety of goods, and reduce wage costs.

The business results of organizing agents in keiretsu groups remained stable, but there were organizing agents who had achieved independent growth by developing a large variety of markets and evolving a large variety of production strategies, as well as newcomers to the field who had developed their own unique products. These responded flexibly to changes in demand both in Japan and overseas 
and bravely developed latent markets, but this was only possible because of the existence of producers with a large variety of skills. Weavers who discovered latent markets were able to develop and produce fabrics they themselves had planned by contracting out some of the work to factories in their vicinity. When spinning companies cut back on their advance payments for cotton yarn and organizing agents increasingly had to pay producers in advance for their cotton yarn, organizing agents in Banshū were not hit too hard because the district's export competitiveness was maintained. This stability in regard to funds was an important condition for organizing agents to continue their positive approach to business activities.

On the other hand, weavers whose production capacity expansion was restricted under the government's equipment registry scheme responded to the rising costs that followed in the wake of the labor shortage by encouraging a cottage or domestic industry through contracting out preparatory processes and reducing the numbers of their own looms, and by making it possible to adjust wage costs and working hours with some flexibility. These measures were possible only because of the existence of young women and elderly people to take on the labor-intensive, simple tasks, as well as of organizing agents who could organize a division of production labor within the district and intensify sales.

Thanks to the growth in demand for yarn-dyed fabrics in the first half of the 1980s and the relative stability of weaving fees, the weavers could take a positive approach to introducing the shuttleless looms that enabled them to raise labor productivity considerably and produce goods of more uniform quality. Labor productivity was improved in the dyeing and finishing industries as well. Because orders for export-oriented fabrics in large lots could be accepted quickly and processing fees remained stable, the shift of producers to small-lot production of many different kinds of products did not adversely affect the work efficiency of producers too much.

But the 1985 Plaza Accord, the stagnation of domestic demand in the 1990s, and the rise of China's textile industry produced environmental changes that greatly changed the conditions under which Banshū's businesses could survive. Faced with a considerable shrinking of exports, a very significant shift to small-lot production of a wide variety of products, sharp drops in the unit prices of fabrics and in pro- 
cessing fees, difficulties in continuity of transactions, technological changes in the preparatory processes, and the ageing of the people engaged in those preparatory processes, the district's businesses and cooperative associations will have to grope their way to new responses.

This article is largely a condensation of Part I of the author's doctoral dissertation submitted to Osaka City University in 2000: "The Evolution and Structure of the Banshū Yarn-Dyed Fabric Industry after World War II." Readers wishing to obtain more details or to follow developments after 1985 can refer to this thesis. 